\title{
GENRE ANALYSIS IN THE SCIENTIFIC PARTICIPATION IN MINERAL TECHNOLOGY
}

\author{
J. Y. P. LEITE ${ }^{1,{ }^{*}}$, A. S. OLIVEIRA ${ }^{2}$, V. N. L. FRUTUOSO ${ }^{3}$ \\ ${ }^{1,2,3}$ Instituto Federal de Educação, Ciência e Tecnologia do Rio Grande de Norte \\ jyp.leite@ifrn.edu.br ${ }^{*}$
}

Received 14/08/2017 - Accepted 23/09/2018

DOI: $10.15628 /$ holos.2018.6523

\section{ABSTRACT}

The participation of women in the scientific area in engineering has been little studied in Brazil and with the mineral technology is no different. With the objective of generating data for the discussion of the subject in the country, a survey of the female participation in the development of scientific activities between the years of 1973 and 2015 was carried out. These data were collected from the Proceedings of the National Meeting of Treatment of Ores and Metallurgy Extractive event that held its first event in 1973, in Rio de Janeiro, under the organization of UFRJ, with 26 events. A pioneer researcher in this area was identified as Profa. Hedda Vargas Figueira (CETEM and UFRJ), who published two
\end{abstract}

articles in the area of Comminution in 1973. During this period, scientific participation was increasing, having surpassed men in recent years. However, it is observed that women do not characterize themselves as leading researchers. The most prominent researcher in this period is Profa. Virginia Sampaio Teixeira Ciminelli (UFMG), with relevant works in the area of hydrometallurgy. It was also observed the increase of publications of articles that only involve women. The work shows strong feminine insertion in science in the area of mineral technology and in teacher renewal these numbers should increase the participation in the academic posts.

PALAVRAS-CHAVE: Mineral technology; genre; woman, mineral engineering; Science, Brasil.

\section{ANÁLISE DE GÊNERO NA INSERÇÃO CIENTÍFICA EM TECNOLOGIA MINERAL}

\section{RESUMO}

A inserção de mulheres na área científica em engenharia tem sido pouco estudada no Brasil e com a tecnologia mineral não é diferente. Com o objetivo de gerar dados para a discussão do tema no país, foi realizado levantamento da participação feminina no desenvolvimento de atividades científicas entre os anos de 1973 a 2015. Estes dados foram coletados a partir dos Anais do Encontro Nacional de Tratamento de Minérios e Metalurgia Extrativa que realizou seu primeiro evento em 1973, no Rio de Janeiro, sob a organização da UFRJ, com 26 eventos realizados. Foi identificada como pesquisadora pioneira nesta área a profa. Hedda Vargas Figueira (CETEM e UFRJ) que publicou dois artigos na área de Cominuição, em 1973.
Neste período, a participação científica foi crescente, tendo ultrapassado os homens nos últimos anos. No entanto, observa-se que as mulheres não se caracterizam como pesquisadoras líderes. A pesquisadora com maior destaque neste período é a profa. Virginia Sampaio Teixeira Ciminelli (UFMG), com trabalhos relevantes na área de hidrometalurgia.

Foi observado ainda o aumento de publicações de artigos que envolvem somente mulheres. O trabalho mostra forte inserção feminina em ciência na área de tecnologia mineral e na renovação docente estes números deverão ampliar a participação nos postos acadêmicos.

KEYWORDS: Tecnologia mineral, Gênero, mulher, engenharia mineral, ciência, Brasil. 


\section{INTRODUCTION}

A study supported by the American literature introduces an overview of the feminist studies of science in relation to the critique of the natural sciences and questions why until today the question of women and / or genre in the sciences has deserved very little attention of the studies social sciences. To conclude, it presents some perspectives for the approaches on women and / or genre and natural sciences in the context of the History of Science in Brazil (Lopes, 2012).

An analysis of the expansion of the undergraduate courses showed that there is a poor distribution of the courses in the country, as well as the average of vacancies is very different between public and private universities. The newest courses also have teachers with less training time and experiences, as well as research activities, illustrated by the total publication of each teacher (Sanches, Bergerman, Del Roveri, 2016). These researchers soon published results of female insertion in the courses, whether as students or teachers.

There is an important gap in this area of research and this work aims to present the feminine insertion in the field of research in the mineral technology area, based on the publications in the Brazilian Meeting of Mineral Treatment and Extractive Metallurgy (ENTMME) and in the post- Strict Sensu from the Mining Engineering area.

The first version of ENTMME was carried out in 1973, by the Federal University of Rio de Janeiro (UFRJ) and coordinated by prof. Roberto Cerrini Villas Boas (Villas Boas, 1973).

\section{MATERIAL AND METHODS}

This work was carried out from data collection in the Annals of National Meetings and Treatment of Minerals and Extractive Metallurgy (ENTMME), the sites of the graduate programs in mineral engineering and the Lattes platform of the National Council for Scientific and Technological Development (CNPq), in order to identify the insertion of women as protagonists in the scientific field in the area of mineral technology.

The Proceedings of ENTMME were consulted at http://searchentmme.yang.art.br with the objective of identifying articles with insertion of women, area of knowledge, year of publication, keywords, quantity of articles with the exclusive presence of women, venue of the event and organizers.

In the sites of postgraduate programs, the number of women with permanent and collaborative work was identified, and how many coordinated the programs. In order to identify the profile of leading teachers of the research group, the platform Lattes of CNPq was consulted. 


\section{RESULTS AND DISCUSSION}

ENTMME was held for the first time in 1973 in Rio de Janeiro and organized by the Federal University of Rio de Janeiro (UFRJ). This is the main event in the technology area of Brazil, where it is already in the 27th edition. Figure 1 shows the evolution of the participation of women with publication of works.

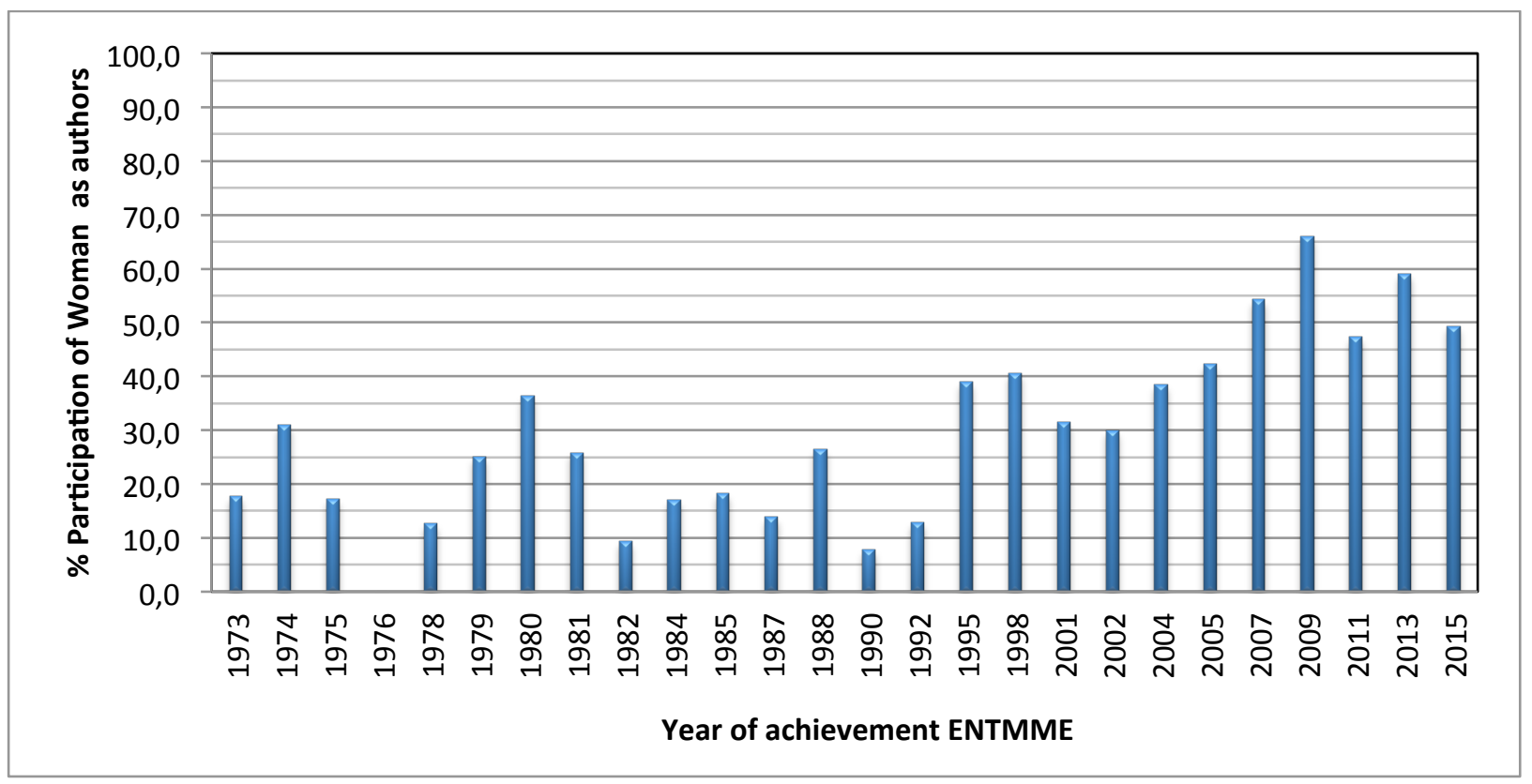

Figure 1. Evolution of the participation of women in the publication of articles in ENTMME.

Observing Figure 1, it can be noted that the insertion of women is increasing throughout the events, and from 2007 these figures present averages above $50 \%$ of the participation in the published articles.

Figure 2 shows the participation of women exclusively in articles published in ENTMME.

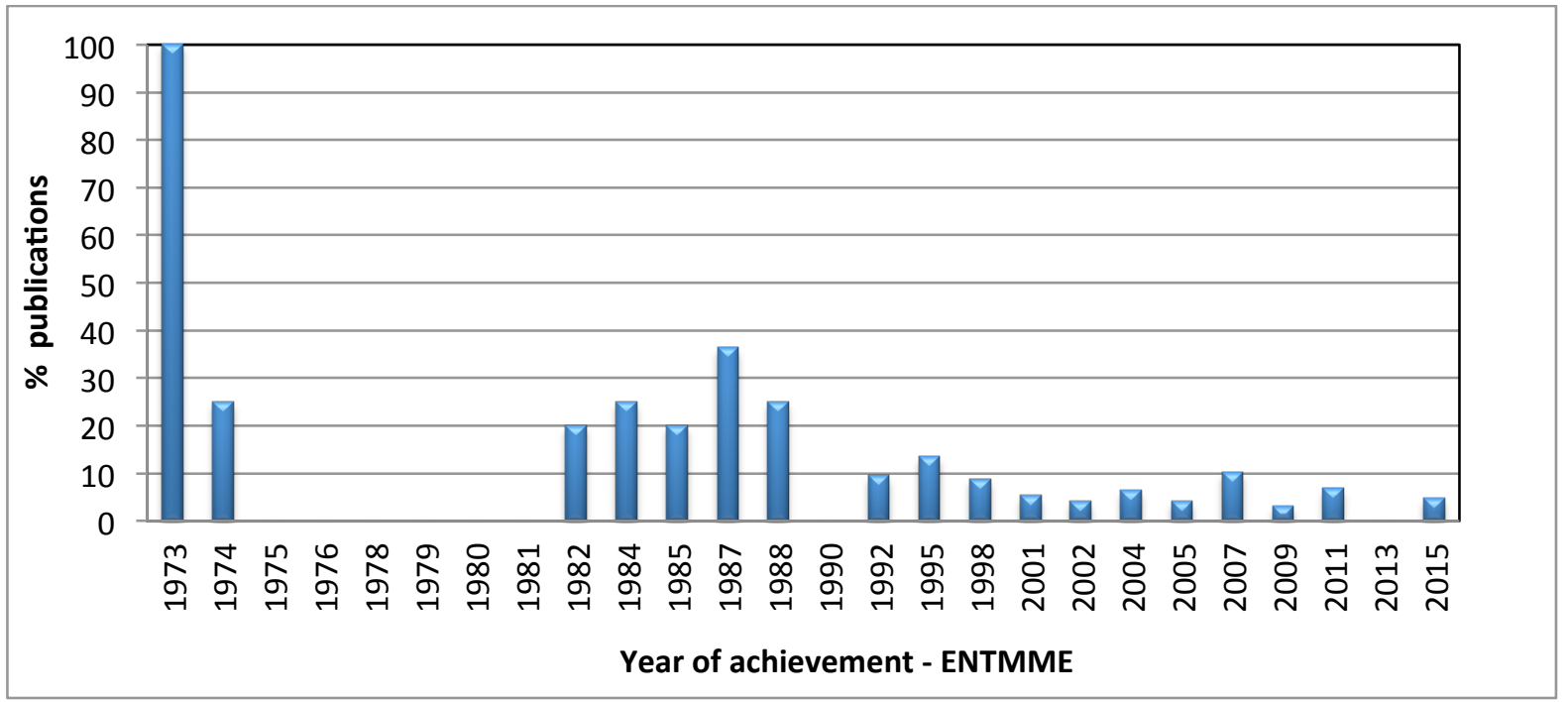

Figure 2. Evolution of publications exclusively for women in ENTMME. 
Analyzing Figures 1 and 2, it can be observed that despite the evolution of female participation in article publications, only those average figures that are of the order of $10 \%$ are still low for the growth expressed in scientific output as a whole.

Most of the Brazilian scientific production comes from the Stricto Sensu postgraduate programs, with the mineral technology area 05 (five) programs registered in the Coordination of Improvement of Higher Education Personnel (CAPES), namely: Federal University of Minas Gerais (UFMG), Federal University of Ouro Preto (UFOP), Federal University of Pernambuco (UFPE), Federal University of Rio Grande do Sul (UFRGS) and Federal University of São Paulo (USP). The programs of UFMG and UFRGS are programs involving metallurgy, mines and materials. The others are exclusive programs of mineral engineering.

Among these, USP and UFMG graduate programs are coordinated by women, with professors Ana Carolina Chieregati (USP) and Sônia Denise Ferreira Rocha (UFMG) representing $40 \%$ of the coordination of postgraduate programs in the country for this area. Table 1 shows the female distribution in these programs.

Table 1. Distribution of women in graduate programs Strict Sensu mineral engineering from Brazil.

\begin{tabular}{|c|c|c|c|c|c|}
\hline \multirow{2}{*}{$\begin{array}{c}\text { Instituition } \\
\text { UFMG }\end{array}$} & \multirow{2}{*}{\begin{tabular}{|c|} 
Teachers Program \\
25
\end{tabular}} & \multirow{2}{*}{$\begin{array}{c}\text { Number of Woman } \\
6\end{array}$} & \multicolumn{3}{|c|}{$\begin{array}{c}\text { Graduate Women } \\
\text { (Permanent - Developer) }\end{array}$} \\
\hline & & & 5 & - & 1 \\
\hline UFOP & 12 & 4 & 3 & - & 1 \\
\hline UFPE & 14 & 4 & 2 & - & 2 \\
\hline UFRGS & 40 & 10 & 7 & - & 3 \\
\hline USP & 12 & 3 & 2 & - & 1 \\
\hline Total & 103 & 27 & 17 & - & 8 \\
\hline
\end{tabular}

Source - Websites of Universities graduate programs. Access in May 2017.

Table 1 shows the inclusion of female teachers in postgraduate programs with an average result of $18.4 \%$, however when they are considered collaborators this number is raised to $26.21 \%$. It is important to note that the professors of the UFRGS program are linked to the area of metallurgy and materials, while that of UFMG is around $50 \%$.

With the objective of analyzing the participation of the professors of the postgraduate programs of this area that act as leaders of research in line of research in the area of mineral technology, a survey was made in the Lattes database of CNPq groups, where Table 2 presents these results. 
Table 2. Distribution of women leaders of research groups from graduate programs Strict Sensu mineral engineering from Brazil.

\begin{tabular}{c|c|c|l}
\hline Graduate program & Leaders & $\begin{array}{c}\text { Mineral Technology } \\
\text { Line }\end{array}$ & \multicolumn{1}{c}{$\begin{array}{c}\text { Research Group } \\
\text { (researcher) }\end{array}$} \\
\hline UFMG & 4 & 2 & $\begin{array}{l}\text { - Mineral processing and Middle } \\
\text { Environment (Sonia Ramirez) } \\
\text { - New S (Virginia Ciminelli) }\end{array}$ \\
\hline UFOP & 1 & 1 & $\begin{array}{l}\text { - Treatment of Ores and Waste } \\
\text { (Rosa Malena Lima) }\end{array}$ \\
\hline UFPE & 1 & 1 & $\begin{array}{l}\text { - Applied Mineralogy and Gemology } \\
\text { (Sandra Barreto) }\end{array}$ \\
\hline UFRGS & 10 & 1 & $\begin{array}{l}\text { - } \\
\text { USP }\end{array}$ \\
\hline & 1 & 1 & $\begin{array}{l}\text { - Mineral Technological Characteriza } \\
\text { of Mineral Raw Materials (Carina Ulse }\end{array}$ \\
\hline
\end{tabular}

Source-CNPq Lattes Platform. Access in may 2017.

The results show that the number of women leading research groups represents only 4 researchers in a universe of researchers / teachers of 103 researchers, representing 3.9\%.

Another important data related to the articles published in the ENTMMEs is associated to the areas, identified by the main keywords in their works. Figure 3 shows a cloud of the main keywords used in their articles published in the ENTMMEs.

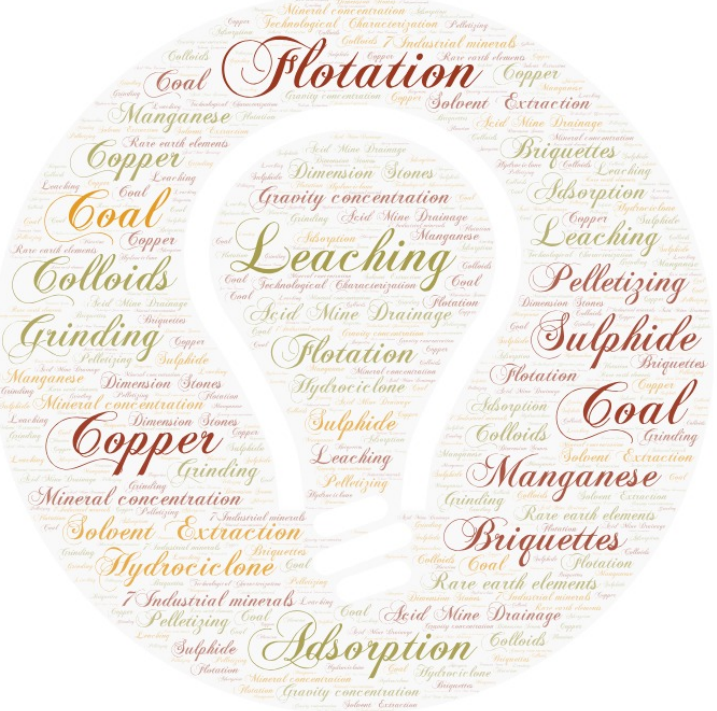

Figure 3. Keywords used by women in the articles in the ENTMMEs. 
The main research themes do not differ from those traditionally published by the academic community. In 1973 the first articles by women in the ENTMME were published by the researchers, namely Hedda Vargas (UFRJ) with the article entitled " Autogenous Grinding ", followed by Zina de Souza Caillaux and Mirian Rosenthal Jocnimek (National Institute of Technology) with the article " Talc study by X-ray diffraction ".

INT researchers have only been identified in this article over the course of events, however Hedda Vargas has five more articles dealing with grinding, gravitational concentration and flotation.

The prof. Hedda Vargas Figueira had a history of mineralogy, teaching at UFRJ, director of the Mineral Technology Center between 1986 and 1988, published articles and books under the seal of CETEM (Branquinho, 2014).

Regarding the organizers of ENTMME, the first participation is registered in the event of 1985 in Natal, with Rose-Mary M. Muzzi (Mineral Development Company - RN) as a member of the committee. Table 3 shows the women who joined the organizing committees in the ENTMMEs.

Table 3. Insertion of women in organizing Committee ENTMME's.

\begin{tabular}{|c|c|c|c|}
\hline Location & Institutions & Year & Organizing Committee (women) \\
\hline Natal & UFRN/CDM/Petrobrás & 1985 & Rose-Mary M. Muzzi-CDM-RN \\
\hline São Lourenço & UFMG & 1992 & $\begin{array}{l}\text { Maria José Salum- UFMG } \\
\text { Virginia Ciminelli - UFMG }\end{array}$ \\
\hline Águas de São Pedro & ABM & 1998 & Monica Speck Cassola-IPT \\
\hline Florianópolis & $\begin{array}{c}\text { UNESC/USP/DNPM COAL } \\
\text { UFSC }\end{array}$ & 2004 & Ingeborg Kuhn - UFSC \\
\hline Natal & UFRN/IFRN & 2005 & Raquel Franco de Souza - UFRN \\
\hline Ouro Preto & UFOP/IPT & 2007 & Monica Speck Cassola - IPT \\
\hline Salvador & UFBA/IFBA & 2011 & Leticia A. Bernardez- IFBA \\
\hline Goiânia & $\begin{array}{c}\text { UFG/PUC/ } \\
\text { UNILASALLE/ } \\
\text { UFRJ/ABM/DNPM }\end{array}$ & 2013 & Elenice Schons Silva - UFG \\
\hline Uberlândia & UFAlfenas/USP & 2015 & $\begin{array}{l}\text { Daniela Garcia Ana Garden } \\
\text { Olivia Barufi Franco Magellan } \\
\text { Carolina Del Roveri } \\
\text { Renata P. Rodriguez }\end{array}$ \\
\hline
\end{tabular}

Source - Annals of the ENTMME's.

Table 2 shows that there is a significant evolution of female participation in recent events.

In 2009, the CETEM Mineral Technology Prize was established at the XXIII ENTMME by the Mineral Technology Center to recognize the two best papers published in the ENTMME, one for 
the ore treatment area and the other for the extractive metallurgy area. To date, there are 04 works awarded for the years 2013 and 2015. In these, the following women are awarded the works: 1) In 2013 - Detection of Bornita, iron deficient sulphide, as a product in the dissolution of chalcopyrite by X-ray diffraction at low angle using synchrotron radiation (Virginia Ciminelli / UFMG, Maria Sylvia S. Dantas / UFMG); 2) In 2015 - Pilot Plant for the Production of Coagulant Ferric Sulfate from Pyrite in Coal Rejects (Angéli Viviani Colling / UFRGS).

To recognize the academic trajectory of researchers in the area of mineral technology, the organization of the XXIII ENTMME instituted the Slawomir Dominik Piatnicki Prize. This event was organized by the mine engineering course at UFGRS.

In 2015, in the XXVI ENTMME, the researcher Virgínia Ciminelli (UFMG) was awarded this honor, taking into account the whole of her work. The researcher is a full professor at UFMG, Level $1 \mathrm{~A}$ researcher at CNPq, having more than 260 publications, among others (CNPq, 2017).

Analyzing the set of data obtained with this work it is possible to verify that in the renewal of the teaching staff of the postgraduate programs, the relation of women has elements to affirm that it will exceed the men in the next 20 years.

The initiative of the organizing committee that held the Goiânia event in 2013 made it possible to make available the ENTMMEs' Annals on the web, which allowed to increase the visibility of those conducting research in mineral technology (Silva, 2013).

The data allows to reflect the need for research in the field of memory in mineral technology, because this field is arid in the literature.

\section{CONCLUSIONS}

The female insertion in research in the area of mineral technology presented average results higher than $50 \%$, from 2007 . The postgraduate programs present an average of around $30 \%$, and it is possible to foresee an amplification in this framework in the teacher renewal process. The data obtained in this work show the need for the expansion of studies in this field, as well as the creation of a space and / or portal to record the history of Brazilian mineral technology. This should be a reason for valuation and dissemination, with a view to encouraging the youth to progress studies in the development of mineral technology.

\section{ACKNOWLEDGMENTS}

We express our thanks to the Directorate of Research and Innovation of Campus Natal Central of IFRN and to FINEP (CT-Mineral Project) for the support to carry out this work.

\section{REFERENCE}

Branquinho, C. L. S. (2014), CETEM 35 Years: Creativity and Innovation, Mineral Technology Center, Rio de Janeiro, 320 pp.

Lopes, M. (2012). "Aventureiras" in the sciences: Reflecting on genre and history of the natural sciences in Brazil.Cadernos Pagu, 0 (10); 345-368 
Sanches, J. G., Bergerman, M. G., Del Roveri, C. (2016). The expansion of higher education in Brazil: a diagnosis of graduate courses in mining engineering. In: XLIV Brazilian Congress of Engineering Education; 2016 September 27-30; Natal, Brazil. (COBENGE). P. 1-9.

Silva, A. C. (2013). Organizing Committee. In: National Meeting of Mineral Treatment, organization. Proceedings of the Brazilian Meeting of Mineral Treatment and Extractive Metallurgy.

Villas Boas, R. C. E. (1973). Organizing Committee. In: National Meeting of Mineral Treatment, organization. Proceedings of the Brazilian Meeting of Mineral Treatment and Extractive Metallurgy. 